\title{
The UN in the Cyprus conflict: UNFICYP
}

$\mathrm{T}$

HE CYPRUS CONFLICT, too, emerged out of a colonial context. In Cyprus, some 6,500 peacekeepers were deployed at a time when, as a result of the Congo experience, several international actors were sceptical of UN peacekeeping. ${ }^{1}$ As of 2002, the Cyprus mission was still continuing. However, its nature had changed considerably since the Turkish intervention in 1974. This chapter focuses on the early years of the operation, when the intra-state dimension of the conflict was arguably more visible. Until the status quo of 1974, the UN Peacekeeping Force in Cyprus (UNFICYP) exhibited more than 'inter-positionary' peacekeeping, which indicates that it had the potential to assume multiple functions and expanded authority, making it a highly instructive case for this study.

As with the Congo, the Cyprus conflict was diagnosed differently by different actors. This chapter will first look at these diverging diagnoses, and then proceed to an examination of how they impacted on the normative synthesis underpinning UNFICYP's operations. Our focus will be on the ambiguous nature of UNFICYP's mandate which arose out of the tensions between the different interests at stake and the normative preferences that accompanied them. The chapter will conclude by examining the implications of this ambiguity for the ensuing normative synthesis.

\section{Historical background}

Cyprus, the home of a Hellenic civilisation, became part of the Ottoman Empire in 1571. The island came under British rule in 1878. During the decolonisation decade, the trilateral Zurich and London Agreements of February 1959 between Britain, Greece and Turkey created the independent 'Republic of Cyprus' in 1960. The 1960 constitution provided for strict powersharing between the Greek and Turkish Cypriot communities. The latter, constituting roughly one-fifth of the total population, was granted veto 
powers over all major legislation, and entitled to a share in governmental, administrative and military services. Archbishop Makarios was elected President by the Greek Cypriots. Dr. Küçük was elected Vice President by the Turkish Cypriots.

In November 1963, Makarios introduced a thirteen-point proposal to amend the constitution in a way that would ensure decision-making by the Greek Cypriot majority, which was rejected by the Turkish community. Intercommunal violence soon erupted, ${ }^{2}$ and the Turkish Cypriot ministers and other officials eventually withdrew from the government. As Clerides, a Greek Cypriot leader, put it in his memoirs:

Just as the Greek Cypriot preoccupation was that Cyprus should be a Greek Cypriot state, with a protected Turkish Cypriot minority, the Turkish Cypriot preoccupation was to defeat any such effort and to maintain the partnership concept, which in their opinion the Zurich Agreement created between the two communities. The conflict, therefore, was a conflict of principle and for that principle both sides were prepared ... to fight, rather than compromise. ${ }^{3}$

While Greek nationalists called for union with Greece (enosis), ${ }^{4}$ Turkish nationalists devoted their efforts to the idea of permanent partition of the island (taksim). ${ }^{5}$ Perhaps the root cause of the conflict was that neither community would agree to be Cypriot and nothing else. ${ }^{6}$ British and UN sponsored mediation efforts failed to restore order. In March 1964 the Security Council would authorise a peacekeeping operation (UNFICYP) on the island.

\section{Prelude to active UN involvement}

The internal strife in Cyprus was first brought to the notice of the Security Council on 26 December 1963 in a letter from the Government of Cyprus, which listed perceived acts and threats against the territorial integrity and sovereignty of Cyprus, and requested the UN to protect the country from unilateral military intervention. ${ }^{7}$ The Cyprus Government, which was by then exclusively in the hands of Greek Cypriots, ${ }^{8}$ declared that it feared a Turkish invasion.

As a result of intensive British diplomacy, on 2 January 1964 Cyprus accepted a proposal by the British, Greek and Turkish governments to take part in a conference in London concerning the future of the island. Britain informed the Secretary-General that the governments of Britain, Greece, Turkey and Cyprus wanted him to appoint a UN observer in Cyprus. ${ }^{9}$ Nevertheless Britain and the United States repeatedly produced plans which largely excluded the UN but included NATO. 


\section{Opposition to the NATO option}

Following the deadlock in London, two Anglo-American proposals for NATO peacekeeping in Cyprus were refused by Makarios:

The position of Archbishop Makarios could be summed up as follows: the principle that an international force should be created and stationed in Cyprus was accepted; such a force, whose composition might be agreed upon in advance, should be under the Security Council; Greek and Turkish units should not participate in the force; and in its terms of reference should include the protection of the territorial integrity of the Republic of Cyprus and assistance in restoring normal conditions. ${ }^{10}$

According to the substantially revised second plan, the proposed peacekeeping force would not be composed exclusively of NATO troops; UN approval would be sought; Britain would send regular reports to the UN SecretaryGeneral; and the Cyprus Government would be kept informed of developments. ${ }^{11}$ However, Makarios made it clear that he would not consent to an international force unless it were placed under the effective authority of the Security Council. Britain and the United States reportedly exerted enormous pressure on the Cypriot Government, even to the point of threatening to obstruct Makarios' efforts at the UN, if he chose to reject the idea of NATO peacekeeping. ${ }^{12}$

Cypriot scepticism of the desirability of a NATO action was understandable, given that Cyprus was a newly decolonised and non-aligned country. However, other considerations had in all probability also motivated Makarios' rejection of the idea of NATO peacekeeping. ${ }^{13}$ In the first place, he felt that in the event of a NATO operation NATO interests would take priority over Greek Cypriot interests. A NATO-based solution would tend to favour Turkish Cypriots as he believed had been the case with the Zurich and London agreements. ${ }^{14}$ Among other things, he also wanted to "escape from the straitjacket of new negotiations with the three guarantor powers alone', make the UN directly 'responsible for' the solution of the Cyprus problem, and isolate the Turks who had fewer friends in the UN than in NATO ${ }^{15}$ Furthermore, the decolonisation sentiment prevailing in the UN might even give Makarios the opportunity to have the London and Zurich agreements (both created under de facto NATO auspices) nullified.

Makarios' position found support especially from the socialist bloc, but also from the non-aligned countries. Soviet policy over Cyprus had been based on two interlinked objectives: to prevent incorporation of the island into NATO, and ensure the abolition of the so-called British sovereign bases in Cyprus. ${ }^{16}$ The Soviet Union saw the prospect of UN peacekeeping as offering the pretext for intruding into an intra-NATO dispute in the eastern Mediterranean. In an all-NATO affair the Soviet Union would have little or no 
say, whereas a UN mission would mean active Security Council involvement, hence an active role for the Soviet Union. Secondly, the situation would give the Russians ammunition to criticise the 'imperialist' tendency of NATO powers. In the Soviet view, the whole crisis typified an imperialist manipulation. First and foremost was Britain's role as the former colonial power which did not want to lose its colonial privileges. In this assessment, Britain was the most important factor contributing to the conflict. The disputed Cyprus Constitution, the argument ran, was specifically designed and imposed by Britain for the express purpose of maintaining its hegemony over the island. ${ }^{17}$ For its part Turkey was seen as harbouring hostile intentions in relation to Cyprus' territorial integrity.

Though de Gaulle's France was at the time more favourably disposed towards the UN than towards NATO, following the fallout of the Congo operation it was less than enthusiastic about the creation of a new UN peacekeeping mission. For France, no external involvement was desirable in Cyprus, whether it be by regional state parties to the conflict (Greece and Turkey), the world powers (especially Britain), NATO, or the UN. Such an attitude would, of course, sooner or later result in enosis. France was indeed on record as favouring enosis as a solution to the Cyprus problem. ${ }^{18}$ If, however, some sort of international involvement was absolutely necessary - and this seemed to be the case - France's preference was to counterbalance AngloAmerican influence over any likely outcome. Given its veto power at the Security Council, the UN option was preferable to the NATO option. ${ }^{19}$

\section{The Anglo-American position}

The United States was mainly concerned to keep and resolve the Cyprus crisis within NATO boundaries. ${ }^{20}$ Greece and Turkey, the guarantor powers of the 1959 agreements, were both within the NATO family, and escalation of the crisis might even cause a war between two neighbours and geostrategic allies. US handling of the situation had to be based on a delicate balance between the Greek and Turkish points of view. ${ }^{21}$ In the presence of an ever stronger nonaligned 'bloc', whose anti-colonial and anti-western orientation was encouraged and provoked by the Soviet Union, the Greek Cypriot case found considerable support among the UN membership. The United States had to be particularly careful not to offend the Turkish side publicly. ${ }^{22}$

A second American consideration was the necessity to counter the Soviet rhetoric of 'NATO aggression'. As the leader of NATO, the United States could not permit Turkey or Britain to be labelled aggressors. NATO's prestige was at stake. Yet another reason for the slight American tendency to support Turkey's viewpoint was Greece's peculiar position. Greece had strong cultural and historical links with Russia, not least in terms of their common Orthodox 
heritage. In addition, both countries had for centuries considered the Ottoman Empire as their common enemy. Moreover, notwithstanding its NATO membership, Greece was home to an influential socialist movement - the American backed Greek junta of 1967 had not yet been installed in Athens. ${ }^{23}$

Britain was opposed to a UN force, because it might diminish Britain's influence in Cyprus. British Defence Minister Thorneycroft had stated in the House of Commons that Cyprus remained the principal base for the British striking airforce, which supported CENTO, and for some substantive units of Britain's worldwide network of military communications. ${ }^{24}$ The strategic importance of the island was unquestionable. ${ }^{25}$ Thanks to its continuing military presence on the island, Britain hurriedly operationalised its own independent 'peacekeeping' operation, which lasted from 21 December 1963 to 27 March 1964.

The British Government brought the situation before the Security Council only when its own troops were no longer able to control the escalating crisis, and when the Greek Cypriot side firmly rejected alternative courses of action. ${ }^{26}$ Britain had not been keen to see a UN peacekeeping operation in the Congo either. In the face of rapid decolonisation, the British tried to maximise their political dominance in what they perceived to be their sphere of influence. With the situation deteriorating, the British delegation finally requested an early meeting of the Security Council. The same day the Cyprus Government asked the Security Council to proceed with the examination of its complaint. These two requests together would form the agenda for the subsequent discussions of the Cyprus question at the Council. ${ }^{27}$

The attempts to resolve the crisis under NATO auspices having failed, the West was left with no choice but to bring the issue to the UN. However, since much was at stake, neither Britain nor the United States could risk leaving the matter entirely in the hands of the General Assembly, where the majority of states were suspicious of possible western neocolonialist intentions. The General Assembly was therefore virtually sidestepped quite early in the process, all the more easily as it was not in session at the time. The General Assembly's formal contribution to the orientation of UNFICYP remained limited.

\section{Resolving two divergent diagnoses}

Two completely different versions of the history of the dispute were presented by the two communities before the Security Council. Largely in response to efforts of the non-permanent members, the Council would choose in its resolutions to ignore the substance of the matter, that is, the root causes of the conflict. The emphasis was instead put on avoidance of renewed violence. ${ }^{28}$ The discussion of UN intervention in Cyprus revolved around concerns over peace, security and sovereignty. The overwhelming majority of the state- 
ments made in the Security Council (as well as the General Assembly) focused on the unity, territorial integrity and political independence of Cyprus. Could UN involvement be directed towards attainment of any other normative objectives? The consensual answer seemed to be in the negative.

For the Soviet bloc, the issue at stake was protection of the territorial integrity and sovereignty of the new Republic of Cyprus against external aggression. While Turkey's claims that it had the right to intervene unilaterally on behalf of the Turkish Cypriot community was identified as the immediate source of the threat, wider NATO interests were considered the actual source of the aggression:

The dispatch of foreign troops to Cyprus has pursued and continues to pursue but one purpose: the actual occupation by the military forces of NATO of the Republic of Cyprus ... The Security Council must ensure the maintenance of peace in Cyprus and in the eastern part of the Mediterranean region. But it is not possible to ensure peace in Cyprus without ending the interference from outside. ${ }^{29}$

In keeping with this view, the Soviet bloc, which insisted on the inter-state dimensions of the conflict, held that the main protagonists were the Governments of Cyprus, Turkey and Britain:

What other interested party in Cyprus, apart from the Government of Cyprus itself, can there be? There is one lawful government in Cyprus, and its representatives are recognized ... as the only lawful representatives of the Republic of Cyprus ... Denktas' ... claim to represent some sort of interested party in Cyprus was clearly an unsuccessful attempt, and one that was not likely to succeed. ${ }^{30}$

The Turkish Cypriots, according to this view, were nothing but a pawn of NATO's imperialist policies. The sovereignty of the Cypriot state rested with the constitutional Cypriot Government, ${ }^{31}$ against whose wishes no UN action could be taken. Since the Soviet bloc defined the Cypriot conflict in terms of 'aggression', it maintained that the Security Council, given the provisions of Chapter VII, had the authority to tell who in the dispute was in the right and who was in the wrong. The UN presence on the island was intended to protect the Cypriot Government, the party alleged to be in the 'right', against the external Turco-British threat.

For the United States, on the other hand, the UN was confronted with a primarily intra-state conflict. The task was to restore domestic law and order by putting an end to the inter-communal strife:

No one is threatening to take the territory of Cyprus, no one is threatening its independence - Turkey or Greece or anyone else ... I repeat that the urgent business before the Council and the responsibility of the Government of Cyprus is to restore communal peace and order and to stop the bloodshed. The sooner that we in the Security Council turn our attention to this, the better it will be for all. $^{32}$ 
The western camp was also more inclined to consider the Turkish Cypriots as a legitimate party to the conflict. Although the Turkish Cypriot community was not explicitly endorsed by the Security Council as a 'party' to the conflict, its representative was granted the opportunity to make a statement before the Council. The difficulty arose from the fact that the Turkish side did not enjoy the legal status of a government. The British representative, nevertheless, took the following position:

The discussion now before us, which arises out of the serious deterioration of relations between the two communities in the Republic of Cyprus, will be materially assisted by hearing a statement from the representative of the Turkish community. ${ }^{33}$

While several representatives would implicitly admit in their speeches that the Turkish Cypriot side was a de facto party to the conflict, and should be recognised as such, there was no specific attempt on the part of the Security Council to identify in any formal sense the parties to the conflict. This would in due course create significant complications for UNFICYP. The agreement, for example, between the UN and the Turkish Government for the re-commencement of the rotation of the Turkish contingent and the parallel removal of roadblocks on the Kyrenia road would provoke great anger amongst the Turkish Cypriots. Regardless of the position taken by the Turkish Government, the Turkish Cypriot leadership held they had not been duly consulted about the agreement. And the road remained blocked. ${ }^{34}$

The overarching concern common to both the socialist and western camps was that, should the Cyprus conflict escalate, peace and stability in the entire eastern Mediterranean would be endangered. In other words, maintenance of international peace and security appeared as the chief concern. However, the situation was so complex that it was simply impossible to determine whether the root causes of the conflict were intra-state or inter-state. As events unfolded, the non-permanent members of the Security Council became convinced that there was little to be gained from trying to establish a causal relationship between the external and internal aspects of the conflict. Instead, the complexity of the situation should be duly acknowledged, and its potential danger for regional stability immediately addressed.

For the non-aligned countries, the most important aspect of the crisis was not the complex interplay between the external and internal dimensions of the conflict, but its implications for the non-aligned cause in the Cold War environment. The representative of Morocco would put the idea in a nutshell: 'From Lattaquie to Tangier, as non-aligned nations, we are deeply attached to the desire that our part of the world should be less and less exposed to the dangers of the cold war'. ${ }^{35}$ The critical issue in this regard was state sovereignty, because the will of the newly independent states to choose their own 
political regime was best captured by this principle. The concept of sovereignty, it was believed, had to include the freedom of a country 'to be the only propounder of its Constitution and to put within that Constitution that which best reflects the rights and guarantees of all communities and citizens' ${ }^{36}$ Nonalignment was a legitimate choice for a country, and the only way to secure that choice was to avoid foreign interference.

\section{Peace and security coupled with sovereignty}

These different views manifested themselves in a common rhetoric, in which several countries, with the exception of the Soviet bloc, preferred to characterise the UN's normative objective as the 'restoration of peace' within Cyprus rather than maintenance of international peace and security. This rhetorical preference resulted mainly from the enormous difficulty in distinguishing between the inter-state and intra-state dimensions of the conflict. Largely as a result of Soviet persistence, however, successive Security Council resolutions would keep their focus on international peace and security. ${ }^{37}$ And given the actors' overarching preoccupation with regional stability, it would be fair to argue that maintenance of international peace and security was indeed the consensual objective prescribed for the UN.

Another characteristic of the UN's response to the Cyprus conflict was the dominance of the sovereignty discourse. Especially in the early stages of Security Council deliberations, all members, regardless of their political stance on the issue, repeatedly referred to such principles as sovereignty, territorial integrity, political independence and non-intervention. There was hardly any reference to human rights, and virtually none to socio-economic development.

The primacy of sovereignty was especially evident in the statements of the socialist bloc representatives:

Our understanding follows from the fundamental principles of the Charter. We are convinced that the Security Council, proceeding from these principles, must deal with the solution of the question before us unequivocally from the point of view of safeguarding the security, independence, sovereignty and territorial integrity of Cyprus ... All other interests must be subjected to this primary objective. $^{38}$

The socialist camp, consistent with its attitude during the Suez and Congo crises, insisted that the UN had to respect and reinforce the sovereignty of Cyprus as embodied in its constitutional government. With frequent references to the colonialist past of some prominent members of the western bloc, the Soviet Union and its allies used every opportunity to cite the 'imperialist' attitude of the NATO allies as the main threat to other states' sovereignty, and hence to international peace and security. 
The principle of human rights was subordinated to sovereignty during the early Security Council deliberations. As the Bolivian representative put it, the Cypriot Government had 'reiterated the unlimited recognition of human rights and the guarantee of individual freedom to all citizens of Cyprus', but 'the importance of this question ha[d] not been debated in the Council'. ${ }^{39}$ Although there was some mention of 'minority rights' in the search for a resolution to the conflict, ${ }^{40}$ systematic emphasis on the importance and promotion of human rights was lacking. ${ }^{41}$ It was not until the news had arrived of several Greeks being deported from Turkey in retaliation for Greek Cypriot ill-treatment of Turkish Cypriots, that the members of the Council began to make specific reference to the necessity of protecting human rights. What is striking is that the scale of the refugee problem on the island was actually comparable to several post-Cold War cases: an estimated 20-25 per cent of the Turkish Cypriot population had become internally displaced or refugee in the course of just a few months. ${ }^{42}$

Even after human rights had entered the discussion, the actors' insistence on the primacy of sovereignty and related principles remained intact. Any reference to human rights was almost always complemented by a more prominent reference to state sovereignty and territorial integrity. This attitude found its parallel in relevant UN resolutions as well. Perhaps the most vivid example was GA Resolution 2077 (XX) of 18 December 1965. In its fifth preambular paragraph, the resolution underlined the importance of the full application of human rights to all citizens of Cyprus, irrespective of race or religion. In the first two operative paragraphs, however, it immediately proceeded to stress the 'sovereignty, unity, independence and territorial integrity of the Republic of Cyprus' and 'the fact that ... Cyprus ... should enjoy full sovereignty and complete independence without any foreign intervention or interference'. ${ }^{43}$ Equally important, the role prescribed for UNFICYP did not encompass human rights or humanitarian aid. The efforts of the UN mission, including both UNFICYP and mediators, were directed towards attainment of 'peace and security', but these concepts were not explicitly linked to the promotion of human rights. Nor is there much evidence to suggest that there was any implicit linkage.

It is also worth noting here that the actors did not necessarily perceive a tension between state sovereignty and human rights. In the words of the Bolivian representative, while the concepts of independence and sovereignty could not be altered and had to prevail over other norms, the Charter also imposed certain obligations on its members, such as respect for human rights. 'In one word,' he asserted, 'the Charter has all the principles and the elements required whereby Cyprus can develop as an independent State and achieve political integration of its inhabitants. ${ }^{44}$ In the context of the Cyprus conflict, international actors did not regard as problematic the reconciliation 
of these seemingly 'incompatible' principles; they did not entertain any tension arising between the requirements of state sovereignty and those of human rights. ${ }^{45}$

\section{Breaking the non-intervention barrier}

Non-intervention was a particularly sensitive issue. The socialist bloc maintained that the essential element, discernible in all decisions of the Security Council on Cyprus, was the confirmation of the principle of non-intervention in the internal affairs of Cyprus and respect for its sovereignty. ${ }^{46}$ Indeed, the potential dangers associated with external interference in Cypriot affairs were a widely shared concern. The Soviet Union and its allies, who were the most outspoken exponents of this view, maintained that no one should be allowed to intervene in the domestic affairs of the new Republic, whether it be a state, a bloc, or, for that matter, the United Nations itself:

Only the people of Cyprus have the right to decide upon their domestic affairs ... The Soviet Union in principle is negatively disposed toward the dispatch to Cyprus of any foreign military forces including United Nations forces . . In order to meet the wishes of the Government of Cyprus, the Soviet delegation is prepared not to hamper the adoption of this draft resolution. ${ }^{47}$

The Soviet Union implied that it actually considered even the initial deployment of UN forces as 'intervention' in Cyprus' domestic affairs. This view indicated a normative dilemma inherent in the Soviet position, in that the UN was expected both to protect the sovereignty of Cyprus against external 'aggression' and not to deploy its forces. Given the request by the Cyprus Government, however, the Soviet Union would eventually tolerate the authorisation of UNFICYP.

The view that the UN should take extreme care in holding on to the principle of non-intervention was shared by France, whose perspective nevertheless differed somewhat from that of the Soviet bloc. Because of its bitter experience in the face of accelerating decolonisation, France was reluctant to support intervention by multilateral organisations. In the end, France would support the authorisation of UNFICYP, but not without reiterating its normative commitment to the principle of non-intervention:

Having regard to the unanimous agreement of the parties concerned on this point, France has not opposed the suggestion despite its reservations concerning the principle of intervention by the United Nations in a military form, particularly if this were to lead to operations involving the use of force. ${ }^{48}$

Not long before, during the Suez crisis, UN intervention had proved detrimental to vital French interests in the canal zone. In the Congo, too, the French 
saw how Belgium's colonial interests had been endangered by an operation shaped primarily by American and Soviet influences. Non-intervention, therefore, was considered a necessary requirement for the protection of French interests.

Soviet and French reservations on UN intervention notwithstanding, several actors did envisage from the outset an active role for the UN in the rapidly-escalating intra-state conflict in Cyprus. These actors did not invoke the principle of non-intervention in the context of Cyprus. Nor did they link UN intervention to the potential international ramifications of the dispute. In other words, they did not necessarily or consistently advocate that the UN, and the Security Council in particular, confine its overall mandate to the maintenance of international peace and security which, as we have pointed out, was the main preoccupation of the western and socialist blocs. The likelihood of the conflict spreading to the international sphere or threatening regional stability was not seen as a precondition for active UN involvement in the conflict. Given the circumstances, the Security Council was simply obliged to act. The statement by the Norwegian representative strikingly illustrates the point:

My Government is deeply concerned over the developments in the area. I would like to say ... what my Government means by "in the area". We mean the situation in the territory of the Republic of Cyprus itself. The Norwegian people and Government do not believe in violence and bloodshed as a means of solving problems within a state; ${ }^{49}$

The Soviet and French insistence on non-intervention was eventually sidestepped thanks in part to the proactive stance taken by those countries which were not in the same camp as the United States and Britain but which were nevertheless in agreement with the Anglo-American policy of introducing the UN into the conflict. No doubt one important element of their support for UNFICYP's establishment was the increasing willingness of the internal parties to see a UN force on the island.

The Turkish side had from the outset demanded an intervention to deal with the 'internal' conflict in Cyprus. ${ }^{50}$ The Greek request, in contrast, had been directed towards the removal of a perceived 'external' threat. As time went on, however, the Greek emphasis shifted slightly towards a preference for a stabilising UN force on Cypriot territory. ${ }^{51}$ The growing willingness of the Greek Cypriot Government to involve the UN in the maintenance of internal law and order was no doubt an important factor in the support given by Third World members to the authorisation of UNFICYP. While extremely sensitive to the issue of sovereignty, as symbolised by the government, the Third World members of the Security Council were not necessarily insistent on the maintenance of international peace and security. ${ }^{52}$ 
An ambiguous mandate acceptable to all concerned

The Security Council's authorisation of UNFICYP came on 4 March 1964 with the adoption of Resolution 186:53

The Security Council,

5. Recommends that the function of the Force should be in the interest of preserving international peace and security, to use its best efforts to prevent a recurrence of fighting and, as necessary, to contribute to the maintenance and restoration of law and order and a return to normal conditions;

The mission had an ambiguous mandate. In the first place, it was not clear how the force would prevent the recurrence of fighting. Secondly, it was not clearly spelt out what 'law and order' and 'normal conditions' referred to. For the Cyprus Government, this meant disarming the so-called Turkish 'rebels'. For the Turkish Cypriots, it meant a return to the order envisaged by the original Cyprus constitution. The Security Council did not provide clarity on these points.

The different expectations of the Greek Cypriots and Turkish Cypriots were reminiscent of the Congo Conflict where Lumumba had assumed that ONUC came to the Congo to enforce his government's authority over all parts of the newly independent state. In Cyprus, Makarios held the same belief with reference to what he portrayed as the Turkish Cypriots' 'secessionist' activities. In the Congo, the Katanga authorities (and after the outbreak of the civil war, the Lumumbist Stanleyville forces) thought that ONUC's duty would be impartial maintenance of law and order without prejudice to their political claims. Similarly, in the Cyprus episode Turkish Cypriots held that UNFICYP should not try to superimpose a political solution on them. The Turkish side's main expectation of the UN was physical protection and prevention of hostilities.

In addition to UNFICYP, SC Resolution 186 authorised a UN Mediator who would 'use his best endeavours ... for the purpose of promoting a peaceful solution and an agreed settlement of the problem confronting Cyprus ... having in mind the well-being of the people of Cyprus as a whole and the preservation of international peace and security'. ${ }^{4}$ The Mediator was to report periodically to the Secretary-General. He would be the political wing of the UN mission in Cyprus. In this authorisation the overarching concern for international peace was explicitly spelt out.

UNFICYP's authorisation resulted from intense discussions. Although the Soviet Union and France preferred a UN force to other alternatives, they were not particularly keen to finance another large-scale and long-term UN force, especially if the objectives of the force were not totally acceptable to them. Their adherence to the principle of non-intervention partly resulted from this consideration. Given the strong British concerns over Cyprus and the 
American interest in keeping NATO affairs out of the UN's sphere, neither the Soviet Union nor France could realistically hope to define the objectives of the proposed UN peacekeeping as they saw fit. Moreover, the parties to the conflict had different expectations of a UN mission.

In these circumstances, UNFICYP's terms of reference were defined rather vaguely. In the words of its sponsors, ${ }^{55}$ the resolution was 'the result of lengthy negotiations, much give-and-take and compromise'. ${ }^{56}$ While it failed to give entire satisfaction to any party, it was not totally unacceptable to them. The subsequent resolutions would share the same fate. At a later stage, one of the sponsors of a subsequent draft resolution would complain that the text they had prepared was so vague as to give the impression that what they were trying to do was to elude or evade debate. Yet this was the only way of achieving agreement and maintaining the mission. ${ }^{57}$ Apart from the vagueness of the mandate, two factors helped overcome the veto threat: unlike the controversial Congo mission, UNFICYP was authorised only for a limited period (three months), ${ }^{58}$ and on the principle that its costs would be met by voluntary contributions.

On 16 January 1964, U Thant appointed Lt-Gen. Gyani of India as his representative in Cyprus. With the adoption of Resolution 186, Gyani became UNFICYP commander. He would be replaced by his countryman Gen. Thimayya on 27 June 1964. In addition to the appointment of Sakari Tuomioja of Finland as UN Mediator, the Secretary-General also sent his successive 'personal representatives' to Cyprus. ${ }^{59}$ In September 1964, the appointment of Galo Plaza (the then personal representative) as the new UN Mediator would give way to a practical merger between the two posts in the form of the Secretary-General's Special Representative.

\section{Authority: expansion within severe constraints}

From the outset, the functions of the UN mission were defined in terms of short-term and long-term tasks. The former belonged with UNFICYP, while the latter was considered more the responsibility of the Mediator. In any case, the scope of the operational tasks was pretty narrow. UN peacekeeping was expected to address the immediate peace and security problems, that is, prevention of active fighting. The Mediator, on the other hand, was tasked with the preparation of a negotiating environment conducive to a permanent resolution of the conflict.

Since UNFICYP's formal mandate was not adequately clear, the Secretary-General felt it necessary to translate that mandate into a clearer set of guidelines and objectives. First, he issued a significant aide-mémoire to the governments concerned. ${ }^{60}$ This document laid down, above all, guiding principles as to the command structure of the operation and principles of 
self-defence. Three weeks later, the Secretary-General would elaborate on the functions of UNFICYP. ${ }^{61}$ The aide-mémoire authoritatively stated that UNFICYP should avoid any action designed to influence the political situation in Cyprus, but contribute to a restoration of order, and create an improved climate in which political solutions might be sought. ${ }^{62}$ In other words, UNFICYP would be a typical limited-scope security mission. It was the Mediator's job to address the political aspects of the situation. In accordance with SC Resolution 186, the aide-mémoire restated that the activities of UNFICYP and of the Mediator were 'separate and distinct undertakings' and should be kept so. ${ }^{63}$

Although the tasks of the force and the Mediator were distinguished by the Secretariat and by several actors, the close and necessary relationship between the two was not overlooked. Norway would argue that:

the immediate and urgent aim must be to prevent the situation in Cyprus from deteriorating and to restore peaceful conditions in the island ... The long-range aspect of the problem, however, must be to create conditions in Cyprus which will remove the distrust, the fear and the lack of confidence now prevailing between the parties, and we believe that the peace force would have very important effect in that regard also. It is with this in view that a proposal has been made for the appointment of an impartial mediator. ${ }^{64}$

There were signs that UN peacekeeping was expected to contribute to a longterm coexistence of the parties by performing wider functions reminiscent of peacebuilding. The Secretary-General did indicate that the two components of the UN's peace mission were not quite separable. If the Force was able to ensure order, this would help the Mediator. If the Mediator made progress, this would facilitate UNFICYP's mandate. The initial distinction between Force and Mediator reflected also the membership's reaction to the Congo experience, where ONUC had become increasingly entangled in the internal military-political struggle. In Cyprus, it was believed, thanks to the careful separation of functions, political problems would be settled by the conflicting parties themselves with the assistance of UN mediation efforts. The effects of the principle of non-intervention were clearly visible here. Solution of domestic problems was the business of the internal parties.

The post of Special Representative was created to relieve the Force Commander of the burden of non-military and political negotiation. It became increasingly apparent that UNFICYP could perform its duties only in direct interaction with synchronised political efforts. Both the Force Commander and the Special Representative would be appointed by the Secretary-General, and the latter would be the chief of the mission. The 1990s would see a systematic application of this method. The two broad functions of peacekeeping and peacemaking would be frequently integrated through Special 
Representatives of the Secretary-General. Furthermore, peacekeeping missions would include a number of political and civilian affairs officers.

The UN Force in Cyprus generally relied on negotiation skills rather than the use or show of force in performing the tasks entrusted to it. In July 1966, in the village of Mora, the commander of the Finnish contingent, Col. Koskenpalo, would ease the escalating tension by shuttle diplomacy rather than deployment of his contingent. At about the same time, another crisis would be prevented in Melousha through similar efforts. While the commander of the Swedish contingent negotiated with the Greek Cypriot guards in the field, UNFICYP's Chief of Staff, Brig. Harbottle, would conduct negotiations with Greek Cypriots at a higher level. ${ }^{65}$ The main implication of such lengthy negotiations between UNFICYP and the internal parties was that, although UNFICYP approached the matters on hand from a technical perspective, both Cypriot communities were wary of the political ramifications of such negotiations.

Formally, UNFICYP had neither a civilian mandate nor an administrative capacity (as would be the case with UNTAC in Cambodia). ${ }^{66}$ Despite the lack of a formal civilian mandate and the absence of formal multifunctional duties, UNFICYP was operationalised by the Secretary-General in a more extensive manner than was originally intended. The Secretary-General's refinement of UNFICYP's vague mandate produced a large number of non-military tasks for the Force. ${ }^{67}$ Stegenga distinguishes between UNFICYP's pacification and normalisation functions. ${ }^{68}$ Whereas the former included mainly military objectives, the latter roughly corresponded to the Force's non-military tasks, such as ensuring freedom of movement throughout the island; eliminating economic restrictions against the Turkish Cypriots; preventing the 'separate' economic development of the two communities; administering the public services; reopening schools and industries; finding land records; getting the judicial system to function normally; facilitating agricultural activities; opening up local and export markets; and supporting human rights. ${ }^{69}$

Soon after deployment, the situation on the ground dictated that UNFICYP perform a great many functions beyond its limited mandate. Faced with a rapidly-evolving situation, the Secretary-General and his experts in theatre also felt that the Security Council should provide a clearer definition for UNFICYP's functions. ${ }^{70}$ The Secretary-General appealed to the Security Council with a request to expand UNFICYP's mandate beyond persuasion and military assistance. If law and order were to be maintained, he argued, the UN personnel should enjoy a greater degree of freedom of action, including complete freedom of movement all over the island, the right to dismantle fortified positions, and the authority to create neutral zones. ${ }^{71}$ The proposed expansion of the UN's authority in the peacekeeping theatre attracted strong opposition from the Soviet bloc: 
We categorically oppose any expansion of the mandate of the United Nations forces in Cyprus in comparison with the way in which that mandate is set forth in the resolution of 4 March. It is quite obvious to us that this would indubitably lead to interference in the internal affairs of the Republic of Cyprus. ${ }^{72}$

In the Soviet view, the UN presence in Cyprus was intended merely to strengthen the competence of the Greek Cypriot Government to maintain law and order. The Soviet Union had made sure that SC Resolution 186 contained a provision to the effect that responsibility for the maintenance and restoration of law and order belonged to no one but the Cyprus Government. ${ }^{73}$ Were UNFICYP to be assigned additional functions, including governmental duties, it might begin to challenge the authority of the Cypriot Government. ${ }^{74}$

From the outset of the mission, 'return to normal conditions' proved a particularly problematic operational objective. Preservation of the status quo could hardly be considered a return to normal conditions. On the whole, the UN tried to avoid a political interpretation of this phrase and concentrated instead on day-to-day economic and social problems. The Secretariat seemed to interpret UNFICYP's mandate beyond military duties. In the view of OsorioTafall, the Secretary-General's Special Representative, the return to normal conditions should enable the two communities 'to resume their normal relations and make it possible for all Cypriots of both communities to go about their normal daily occupations anywhere in the island in greater freedom and unimpaired security'. ${ }^{75}$ For U Thant, too, this phrase referred to a normalisation of civilian life. ${ }^{76}$

More was expected from the normalisation of civilian life than the mere absence of immediate violence. Although that much was clear, the parties entertained quite different notions as to the meaning and content of normalisation. The Turkish interpretation foresaw a return to the situation that had existed before the fighting began in December 1963 and a restoration of the original 1960 Constitution. It was the proposed changes to that Constitution that gave rise to the conflict in the first place. For the Greek side, normalisation meant, first and foremost, the removal of de facto Turkish enclaves, and preferably a radical reorganisation of the constitutional system of the Republic.

The vague wording of the mandate did leave the door open to a wider interpretation - especially the provisions for normalisation and order. The situation on the ground more or less dictated that, if peace were to be achieved, the UN would have to deal with more than just territorial integrity. One example where UNFICYP performed non-military duties involved the work of economic officers attached to UNFICYP contingents. The task of these officers was to find ways in which Turkish-owned factories in the Greek sector and Greek-owned factories in Turkish towns would be free to operate. UNFICYP also helped with Greek-Turkish joint projects for soil conservation 
and water development. The mission was concerned, at least in an embryonic sense, with establishing the socio-economic preconditions of peace and security. ${ }^{77}$

UNFICYP, to a certain degree, assumed two functions which have traditionally belonged to governments: physical protection of individuals and provision of services. ${ }^{78}$ The mission affected Cyprus' economy as well. In these circumstances it was unrealistic to expect UNFICYP not to intervene in the domestic affairs of the host state. To be more precise, it was not realistic to exclude the possibility that some parties to the conflict and some UN members would consider UN efforts as intervention in Cyprus' internal affairs. As one analyst puts it, 'any agency that provides police protection and welfare to a dislocated society cannot remain neutral politically'. ${ }^{79}$ In the 1990 s, however, the objection to this notion of non-intervention would diminish. The inclusion of numerous tasks within the job description of UN peacekeepers, although not always appreciated by the conflicting parties, would become less and less objectionable for the UN membership.

A very early warning as to the limitations of UN authority (as exercised by the Security Council) vis-à-vis intra-state conflicts came from non-permanent members of the Council:

There is no merit in the Council discussing whether these treaties and the Constitution that was adopted were good or bad. It is the view of my Government that it is not for the Security Council to pronounce upon the Constitution of a Member State, nor to pass judgment on a set of treaties which were negotiated as an integral part of the whole process of granting independence to that State. ${ }^{80}$

Lengthy debates about the domestic arrangements and the constitutional order in Cyprus were considered neither useful nor appropriate. It was not the business of the Security Council to pronounce what was 'good' or 'bad' for the internal functioning of a member state. Typically, the creation and nature of a country's constitution were considered integral to its domestic affairs. ${ }^{81}$

The British attitude, however, was more 'interventionist' in that it pointed to certain expectations as to proper governmental conduct. Britain held - though without questioning the legal standing of the Greek-held Government - that the Government in Cyprus, like any other government, was under an obligation to maintain security within its territory and to observe the Constitution under which it was created and which authorised its representatives to speak on behalf of the Republic. ${ }^{82}$

The Secretary-General's aide-mémoire had moved towards asserting the UN's normative authority. Having maintained that UNFICYP should 'undertake no functions which are not consistent with the definition of the function of the Force ...', paragraph 9 dealt with the question as to who would judge whether proposed actions were consistent with the mandate or not: 'Any 
doubt about a proposed action of the Force being consistent with the definition of the function set forth in the resolution must be submitted to the SecretaryGeneral for decision'. Despite the scepticism of some influential members, among them the Soviet Union and France, the Secretariat was asserting the UN's referee role embodied in the person of the Secretary-General. ${ }^{83}$ It was obvious from the beginning that the Greek and Turkish interpretations of UNFICYP's mandate differed substantially, and that the two sides had different expectations of the mission. The Secretary-General was of the view that the UN, in his person, should have the final say over the course of action to be taken. Not every decision could be left to the parties' consent.

Paragraph 13 underlined the clear distinction to be drawn between the troops of the British contingent in UNFICYP and the other British military personnel in Cyprus. The Secretariat was thereby trying to dissociate UNFICYP from one of the international parties to the conflict, which also happened to be a permanent member of the Security Council. Taken together with paragraphs $4-7$, on the other hand, paragraph 13 gave the clear message that the British contingent in the Force would be under the exclusive command and control of the Secretary-General through the intermediary of the Force Commander. The Secretary-General went even further in his aidemémoire, expressing the desire to see both Greek and Turkish troops stationed in Cyprus brought under overall UNFICYP command, even though, as he clearly admitted, the UN had no specific mandate to require this. ${ }^{84}$

UNFICYP was quite hesitant to use or threaten force in the performance of its functions. In November 1967, during the notorious Kophinou incident, the Force chose not to intervene in the fighting in the face of a determined and large-scale Greek Cypriot offensive. The guidelines for self-defence and for the use of armed force, which were outlined in the aide-mémoire, ${ }^{85}$ were more detailed than those in the Congo operation. The key provisions were that the use of armed force was permissible only in self-defence, and that the principle of minimum force should be applied. As a general rule, UNFICYP was allowed to use force only when all peaceful means of persuasion had failed. ${ }^{86}$ The Force was prohibited to take any action which was 'likely to bring [it] into direct conflict with either community in Cyprus'. However, it was authorised to use force 'where specific arrangements accepted by both communities [had] been, or in the opinion of the commander on the spot [were] about to be, violated, thus risking a recurrence of fighting or endangering law and order'. ${ }^{87}$ Examples in which troops might be authorised to use force included 'attempts by force to prevent [UNFICYP personnel] from carrying out their responsibilities as ordered by their commanders'. 88

The guidelines, as expressed in paragraphs 17 and 18, had created a vast space in which the issue of the use of force could be entertained. In a sense, rather than actually specifying the conditions for the use of force, these guide- 
lines had established the justification of any line of action, and added to the UN's authority in Cyprus. If UNFICYP intended to take enforcement action against either party, for instance, these two provisions might provide an excellent umbrella, though, as demonstrated in the case of Kophinou, it would not be realistic to anticipate coercive UN action, given the likely international repercussions.

In a subsequent report, U Thant provided further specifications for the use of force, ${ }^{89}$ in particular the specification that UNFICYP was 'reasonably entitled to remove positions and fortified installations where these endanger the peace .... It was not, however, altogether clear whether the peace in question would have to be international to warrant UN action. He also added that UNFICYP could demand 'that the opposing armed forces be separated to reasonable distances in order to create buffer zones . . . ${ }^{90}$ Though these clarifications were more explicit than the ones before, the ambiguity surrounding the principle of non-use of force persisted. In any given situation, UNFICYP might or might not choose to use force, and both choices would be equally and perfectly justifiable within the available guidelines.

\section{Concluding observations}

The UN's involvement in the Cyprus conflict reflected a dominant preoccupation with the maintenance of regional stability, and in that sense international peace and security. A second principle that featured prominently, as in the Congo case, was state sovereignty, expressed almost exclusively in its external dimension. Here again a striking silence surrounded the issue of human rights, which was only sporadically addressed - usually in terms of 'minority' rights.

Considerable tension emerged between two opposing views as to the nature of the conflict and the approach to be adopted by the UN. As with the conflict in the Congo, this tension was best symbolised by the Anglo-Soviet disagreement. Britain again strongly favoured the Hammarskjöldian 'peacekeeping' formula, insisting on strict adherence to the principle of impartiality/neutrality. The Soviet Union, in line with the attitude it took during the ONUC episode, initially emphasised the prevention of 'external' threats to Cyprus' sovereignty, portraying the Turkish Cypriot claims as 'secessionism' fuelled by colonial/imperial ambitions. The socialist bloc, whose position was again directed towards securing the support of the nonaligned world, endorsed the Hammarskjöldian formula only after the Greek Cypriot Government had extended its consent to UN peacekeeping. One factor behind the eventual Soviet toleration was, no doubt, the fact that the Cyprus conflict was taking place practically within the US sphere of influence rather than in a relatively 'neutral' zone, with Greece and Turkey directly involved. 
The US role was again crucial in synthesising diverse normative preferences. Washington carefully supported the British and Turkish positions, moderated the Greek attitude, and counterbalanced Soviet pressure. The ambivalent voices from the South also contributed to the reconciliation of conflicting interests and normative prescriptions. In the ensuing normative synthesis, consent emerged as the critical factor. Value was attached both to the de jure consent extended by the Government and the de facto consent extended by other parties to the conflict. For UNFICYP to materialise the politically indispensable element was certainly Greek Cypriot consent. Yet what was crucial to the normative synthesis was the consent given by both the Turkish Cypriot community and Turkey. Given the Anglo-Soviet disagreement and the Third World's ambivalent position, this ensuing normative 'synthesis' may not have emerged, had either party to the conflict adopted a negative attitude, as was the case in the Congo. The normative preferences expressed by international actors were all along premised upon this dual consent.

At the local/regional level the Greek and Turkish sides as well as Greece and Turkey, and at the geopolitical level the western and socialist blocs had different expectations of UNFICYP. The mission was authorised and operationalised in a way that was acceptable to the Greeks and Turks on the one hand, and to Britain and the Soviet Union on the other. Predictably, UNFICYP's mandate was surrounded by ambiguities - what might be called 'resolution by ambiguity'. The authority assigned to the UN was necessarily constrained, because the interests that were temporarily reconciled through the introduction of a UN presence on the island were diametrically opposed to each other, and a stronger multilateral intervention would have been deemed by all parties concerned, including the superpowers, to be prejudicial to their interests.

The vague wording of the formal mandate, with its ambiguous references to 'normalisation' and 'law and order', made it possible for UNFICYP to adapt to the changing conditions in the peacekeeping theatre. The UN's role in 'governance' remained, however, negligible throughout. A more flexible and slightly expanded implementation of the mandate was tolerated and even encouraged, but only so long as the de facto consent of the parties continued. In general, the UN's authority in Cyprus was defined within the parameters of the Hammarskjöldian formula. UNFICYP was expected to use force only in self-defence, and most importantly, to remain 'neutral'. Taken at face value, neutrality simply meant not favouring one intra-state party at the expense of the other. At a deeper level, it meant refraining from taking sides in the context of either regional (Greece vs. Turkey) or global (United States vs. Soviet Union) conflict.

The Cyprus mission demonstrated a sharp contrast with the Congo, and 
was for this period more the 'rule' than the 'exception'. Active UN involvement was attributable partly to the fact that Britain was desperate to maintain its foothold in Cyprus, and partly to the special ties that Greek and Turkish Cypriots had with Greece and Turkey respectively, both of which, it should be stressed, were part of the US alliance system. Having experienced the tensions and contradictions associated with the Congo episode, the international community, and especially the key actors, were wary of involving the UN in the active 'settlement' of the conflict. The emerging normative synthesis reflected minimalist prescriptions for the UN, in which consent and neutrality emerged as the key factors.

\section{NOTES}

1 The estimated population of Cyprus in 1965 was 582,000: see United Nations, World Population Prospects 1990, p. 368. The ratio of UNFICYP's strength to the local population was 110/10,000.

2 On 21 December 1963, Greek Cypriots, acting in accordance with a 'top secret' plan, attacked the Turkish Cypriots. The Akritas Plan was first published in the Greek Cypriot newspaper Patris on 21 April 1966 'with the professed intention of exposing the mishandling of the Greek Cypriot cause by Archbishop Makarios': see Z. M. Necatigil, Our Republic in Perspective (Nicosia: Tezel, 1985), p. 4. For full text of the Akritas Plan, see A/33/115-S/12722 of 30 May 1978.

3 G. Clerides, Cyprus: My Deposition, vol. 3 (Nicosia: Alithia, 1990), p. 105.

4 All Greek Cypriot newspapers on 28 October 1964 covered Makarios' statement: 'Greece has come to Cyprus, and Cyprus is Greece. I firmly believe that the PanHellenic struggle for the union of Cyprus with motherland Greece will shortly be crowned with success. This success will be the beginning of a new era of Greek grandeur and glory'. See www.turkishforum.com/cyprus/enosis_statements1.html (27 March 2001).

5 Reportedly, Dr. Küçük was of the view that the partition of the island might be the only solution to the Cyprus problem: see M. Wall, 'Agreement on Neutral Zone in Cyprus', the Guardian (31 December 1963).

6 This diagnosis by the Togolese delegation seems fairly accurate: see GAOR, First Committee, 1409th meeting (13 December 1965).

7 S/5488 of 26 December 1964.

8 Dr. Küçük and the three Turkish Cypriot ministers kept their titles until 1967, but were prevented from returning to their offices by the Greek Cypriot national guard: see A. C. Gazioglu and M. A. Demirer (eds), Cyprus: The Island of Sustained Crises, 2nd edn (Nicosia: CYREP, 1999), p. 17.

9 S/5508 of 8 January 1964.

10 The British representative outlined both proposals (dated 31 January 1963 and 12 February 1964 respectively) before the Security Council: see S/PV.1095 of 18 February 1964, pp. 22-45; quotation from pp. 32-3.

11 Keesing's Contemporary Archives, 14:2 (13-20 June 1964): 20117.

12 J. A. Stegenga, The United Nations Force in Cyprus (Ohio: Ohio State University Press, 1968), p. 179.

13 See J. S. Joseph, Cyprus: Ethnic Conflict and International Concern (New York: Peter Lang, 1985), pp. 202-5. 


\section{The UN in the Cyprus conflict}

14 G. S. Kaloudis, The Role of the U.N. in Cyprus from 1964 to 1979 (New York: Peter Lang, 1991), p. 35.

15 Stegenga, The United Nations Force in Cyprus pp. 57-8.

16 R. McDonald, The Problem of Cyprus (London: IISS, Adelphi Paper No. 234, Winter 1988/89), p. 67.

17 In this regard, the Kenyan representative at the UN saw a parallel with the original constitution of Kenya at independence, which created an artificial distinction between 'major tribes' and 'pastoral small tribes' and was allegedly designed to weaken the Central government vis-à-vis the semi-autonomous provinces: see GAOR, First Committee, 1409th Meeting (13 December 1965).

18 P. Windsor noted by Stegenga, The United Nations Force in Cyprus, pp. 46, 199.

19 The pro-Greek, anti-NATO stance of France is noted in Joseph, Cyprus: Ethnic Conflict and International Concern, p. 180.

20 Upon intensifying criticism, the US Secretary of State, Dean Rusk, felt it necessary to deny publicly that the United States was in fact afraid to let the Cyprus issue come before the Security Council: see US Department of State Bulletin (2 March 1964), pp. 332-3.

21 George Ball, the then US Under-Secretary of State, writes: 'Cyprus was a strategically important piece of real estate at issue between two NATO partners: Greece and Turkey. We needed to keep it under NATO control.' See W. G. Ball, The Past Has Another Pattern: Memoirs (New York: W. H. Norton, 1982), p. 342.

22 Behind the scenes, however, one of the strongest warnings to Turkey came from President Johnson in his letter to the Turkish Prime Minister (5 June 1964); for the full text and a comment, see E. Erner, Davulun Sesi: Disislerinde 44 Yil (Ankara: Bilgi, 1993), pp. 104-6, 256-64.

23 In November 1999 Clinton publicly expressed his regret for the US support to the Greek junta of 1967. 'When the junta took over in 1967,' Clinton said, 'the United States allowed its interests in prosecuting the Cold War to prevail over its interest, I should say its obligation, to support democracy, which was, after all, the cause for which we fought the Cold War. It is important that we acknowledge that.' See http://cjonline.com/ stories/112199/new_usgreece.shtml (29 March 2001).

24 See The Times (London) dated 20 February 1964 cited in the Soviet statement in S/PV.1097 of 25 February 1964, pp. 97-100.

25 The island was strategically important also for the overall NATO umbrella. Reportedly, the CIA had constructed monitoring stations in Cyprus in 1949 under an agreement with Britain. Furthermore the presence of British troops on the island was expressly described as being in the interest of NATO: see McDonald, The Problem of Cyprus, p. 55.

26 The British Secretary of State for Commonwealth Relations and for the Colonies, Duncan Sandys, tried to justify his Government's attitude as follows: 'There seemed to us to be serious objections to the proposal that the United Nations should be asked to assume full responsibility for creating and controlling the required international force. The transfer of the argument to the Security Council would not in itself solve the difficulty in reaching agreement upon the composition and terms of reference of the force.' See UK House of Commons, Hansard Debates, Fifth Series, vol. 689, cols 840-3.

27 Both letters were dated 15 February 1964: see S/5543 and S/5545 respectively.

28 The Bolivian representative pointed out that the Security Council chose not to examine the substance of the matter, in view of the fact that new violence must be avoided at all costs: see S/PV.1139 of 20 June 1964, p. 16.

29 Soviet statement before the Security Council: see S/PV.1096 of 19 February 1964, pp. $13-15,22$. 


\section{The UN, intra-state peacekeeping and normative change}

30 Soviet statement before the Security Council: see S/PV.1099 of 28 February 1964, p. 12.

31 Czechoslovakia maintained that the constitutional Government of Cyprus was 'the sole representative of the national sovereignty': see S/PV.1139 of 20 June 1964, p. 7.

32 US statement before the Security Council: see S/PV.1096 of 19 February 1964, p. 36.

33 British statement before the Security Council: see S/PV.1098 of 27 February 1964, p. 21.

34 A. Duncan-Jones, 'The civil war in Cyprus' in E. Luard (ed.), The International Regulation of Civil Wars (London: Thames \& Hudson, 1972), pp. 160-1.

35 See S/PV.1097 of 25 February 1964, pp. 18-20.

36 See the statement by Morocco in S/PV.1097 of 25 February 1964, pp. 13-15.

37 The exception was SC Resolution 193 of 9 August 1964, which called upon the parties to cooperate in the 'restoration of peace and security'.

38 Statement by Czechoslovakia before the Security Council: see S/PV.1097 of 25 February 1964, pp. 38-40.

39 S/PV.1139 of 20 June 1964, p. 12.

40 Ironically, the 'minority rights' discourse was in any case not acceptable from the Turkish perspective. All along the Turkish Cypriots had made it clear that they "must not be regarded as a minority, but accepted as a separate community, on an equal footing': see A. C. Gazioglu, Two Equal and Sovereign Peoples: A Documented Background to the Cyprus Problem and the Concept of Partnership (Nicosia: CYREP, 1997), p. 43.

41 See also General Assembly First Committee discussions in A/C.1/1407-1414 of 11-15 December 1965.

42 See K. Kyle, Cyprus: In Search of Peace (London: Minority Rights Group International, 1997), p. 12; Turkish Ministry of Foreign Affairs, Cyprus: 7 Questions and Answers (Ankara: July 1999), p. 10.

43 The resolution was adopted by 47 to 5 , with 54 abstentions. It was mainly the nonaligned countries which voted in favour. Turkey, the United states, Albania, Iran, and Pakistan voted against. The 54 abstentions included both the western and the socialist bloc, both of which were reluctant to further irritate Turkey: see J. S. Joseph, Cyprus: Ethnic Conflict and International Politics - From Independence to the Threshold of the European Union (Houndmills: Macmillan, 1997), p. 110.

44 S/PV.1098 of 27 February 1964, p. 97.

45 The primacy assigned to sovereignty was, nevertheless, apparent in such statements as the one made by the Ivory Coast: 'The sovereignty and territorial integrity of a Member State ... cannot be subordinated to anything whatsoever ... We should, in conformity with the Charter, reaffirm the sovereignty and territorial integrity of Cyprus as well as the need, flowing from respect for human rights, to protect and guarantee the rights of the minority.' See S/PV.1097 of 25 February 1964, pp. 52-5.

46 Soviet statement in S/PV.1153 of 17 September 1964, pp. 43-5.

47 Soviet statement before the Security Council: see S/PV.1102 of 4 March 1964, pp. 3-6.

48 French statement before the Security Council: see S/PV.1102 of 4 March 1964, p. 21.

49 While Norway made it clear that it did "not believe in intervention from the outside in order to bring about a certain solution to tragic differences between various parts of the population of any Member state', these words were not intended to discourage UN intervention. Rather they underlined the normative position that no outside solution could be imposed on the parties: see S/PV.1103 of 13 March 1964, p. 72.

50 See the Turkish statement in S/PV.1099 of 28 February 1964, p. 72.

51 The Cyprus Government held that the UN force could enter Cyprus to help the 


\section{The UN in the Cyprus conflict}

Government in restoring internal peace and normal internal conditions: see S/PV.1099 of 28 February 1964, p. 71.

52 The Ivory Coast held: 'The Security Council must immediately put an end to the massacres ... According to press reports, the Government of Cyprus hopes to see a United Nations force ... May we take this as an invitation to the United Nations to intervene? My Government believes so.' See S/PV.1097 of 25 February 1964, p. 51.

53 The mission's mandate would be hardly modified in the following two years; see SC Resolutions 187 of 13 March 1964; 192 of 20 June 1964; 193 of 9 August 1964; 194 of 25 September 1964; 198 of 18 December 1964; 201 of 19 March 1965; 206 of 15 June 1965; 207 of 10 August 1965; 219 of 17 December 1965.

54 Operative para. 7.

55 Bolivia, Brazil, Ivory Coast, Morocco and Norway, that is, all non-permanent members of the Security Council except for Czechoslovakia.

56 See the statement by Brazil in S/PV.1100 of 2 March 1964, pp. 4-5. In due course, this vagueness would hamper the mission's effectiveness and even constitute another source of conflict as was argued by the Ivory Coast in S/PV.1155 of 21 September 1964, p. 16.

57 This point was explicitly spelt out by Bolivia: see S/PV.1159 of 25 September 1964, pp. $12-15$.

58 UNFICYP's continuation was subject to periodic Security Council approvals. This would create a significant difficulty for peacekeepers, since they did not know, until a few days before a mandate was due to expire, whether the mission would continue: see Lt. Col. Martin's remarks in Stegenga, The United Nations Force in Cyprus, p. 163.

59 Spinelli, Plaza and Bernardes.

60 S/5653 dated 10 April 1964.

61 S/5671 dated 29 April 1964.

62 Para. 2.

63 Para. 15.

64 S/PV.1097 of 25 February 1964, p. 26.

65 Duncan-Jones, 'The civil war in Cyprus', p. 153.

66 N. Sambanis, 'The United Nations operation in Cyprus: a new look at the peacekeepingpeacemaking relationship', International Peacekeeping, 6:1 (Spring 1999), 91.

67 See S/5671 dated 29 April 1964.

68 J. A. Stegenga, 'UN peace-keeping: the Cyprus venture', Journal of Peace Research, 8:1 (1970).

69 Kaloudis, The Role of the U.N. in Cyprus, pp. 59-60.

70 See the statement by Ivory Coast in S/PV.1159 of 25 September 1964, pp. 7-10.

71 See the supportive statement by Morocco in S/PV.1155 of 21 September 1964, p. 22.

72 Soviet statement before the Security Council S/PV.1153 of 17 September 1964, pp. $48-50$.

73 Operative para. 2 asked 'the Government of Cyprus, which has the responsibility for the maintenance and restoration of law and order, to take all additional measures necessary to stop violence and bloodshed in Cyprus.'

74 Czechoslovakia had earlier maintained that the coexistence of the two communities was the exclusive 'responsibility of the Cypriot Government': see S/PV.1097 of 25 February 1964, pp. 41-5.

75 UN Press Release CYP/521 of 25 June 1968.

76 'A great deal remains to be done to bring about real progress towards a return to normal conditions in civilian life': see S/9233 of 3 June 1969.

77 Duncan-Jones, 'The civil war in Cyprus', p. 161. 
78 Heye notes that 'an important part of the work of the military peacekeepers in UNFICYP was to negotiate the restoration of public services and ensure that they operate efficiently, and establish clinics and stock them with medical supplies'. See Heye, 'United Nations peacekeeping', p. 12 .

79 Stegenga, The United Nations Force in Cyprus, p. 150.

80 Norwegian statement before the Security Council S/PV.1097 of 25 February 1964, p. 22.

81 In addition to Morocco's view mentioned above, see the statement by Ivory Coast in S/PV.1097 of 25 February 1964, p. 51.

82 S/PV.1098 of 27 February 1964, pp. 43-5.

83 The Soviet Union was especially critical of the extensive role the Secretary-General was given. This objection owed much to the Congo experience. Here we should recall the acrimonious Khrushchev-Hammarskjöld debates about the functioning of ONUC. As a result of the objections raised by the Soviet Union and France, paragraph 4 of SC Resolution 186, which defined the role of the Secretary-General in relation to the Cyprus mission, was subjected to a separate vote, but in the end adopted.

84 Para. 11.

85 Paras 16-19.

86 Para. 18.

87 Para. 17 (c).

88 Para. 18 (c).

89 S/5950 dated 10 September 1964.

90 Para. 215. 